

\title{
China, Oil, and Africa: A New Perspective
}

\author{
CYRIL OBI*
}

ABSTRACT This commentary provides insights into the evolving trajectories of China-Africa relations by drawing on a case study of the place of a strategic natural resource, oil, in the evolving relations. It unpacks the nature of China's engagements with Africa's oil-producing states and challenges the views of those who claim that emerging China-Africa relations are based on a "new colonial" scramble for Africa's resources, particularly oil. The commentary advances an alternate view based on Africa's agency in shaping its relations with China and posits that African petrostates and elites are in a position to determine if the outcome of oil engagements with China will connect to a project of national and continental development, or not.

\section{Introduction}

n the recently concluded Forum on China-Africa Summit, held from September 3-4, 2018 in Beijing, President Xi Jinping of China announced that his country had implemented ten cooperation plans and delivered on its $\$ 60$ billion pledge of financing to Africa within the framework of development cooperation since the 2015 FOCAC Summit held in Johannesburg, South Africa. ${ }^{1}$ With

* Social Science Research Council (SSRC), U.S.

Insight Turkey Vol. 21 / No. 1 / 2019, pp. 11-23 China-Africa trade topping $\$ 200$ billion in 2017, the latest FOCAC meeting held in Beijing, and attended by 53 of Africa's 54 states, marked a "critical milestone" in China-Africa relations. The growing ties between Africa and the continent's largest trading partner, China, ${ }^{2}$ have attracted attention both within the continent and across the world. Speaking at the FOCAC meeting, President Cyril Ramaphosa of South Africa expressed Africa's expectation of China's continued support and partnership in helping Africa realize its great potential. ${ }^{3}$ There is no doubt that the rise of China as an emerging power from the Global South holds great symbolism for Africa's ruling elites, who clearly hold the expectation that Africa can benefit both from the "demonstration effect" of China's feat, as well as its support, to transform the continent and renegotiate its place in an emerging global order. 
It is only when the agency of African states and ruling elites are considered alongside heterogeneous Chinese economic actors that we are able to move away from simplistic assumptions, and unpack relations involving a complex set of interests on both sides the debates over the impact of China on Africa's development as involving three schools of thought. ${ }^{8}$ These include those that see China's relations with Africa as a threat to the West's economic and security interests, skeptics who are wary of the effects of China's development cooperation on traditional Western aid conditionalities and effectiveness, and pragmatists who are more interested in the opportunities that the expanding engagements can open up on both sides. Rather than support any of the competing perspectives, he makes a compelling case for the primacy of "African agency," arguing that it is African states and the roles of their leadership or ruling elites and institutions that will ultimately determine the outcome of the growing ties between China and Africa.

As the debate over the nature of China-Africa relations continues to rage, the place of Africa's natural resources cannot be overlooked, particularly in the face of increased global interest in the continent as a source of industrial and strategic raw materials and markets for finished goods. It is therefore important to critically examine the place of natural resources in the evolving relations, both in terms of their developmental potential for the continent and as an object of Chinese engagement with Africa. In this regard, this essay will examine the emerging trajectories in China-Africa oil relations.

As the world's largest importer and consumer of crude oil in 2017, China has become a significant player on the 
global energy scene. Apart from its reliance on sources from other parts of the world, its "go out policy" has also included rapid growth in global oil investments by Chinese State Oil Corporations (SOCs). Africa's status as one of the prolific frontiers of growing oil production is therefore of strategic interest both to China's energy security and to investments by its SOCs. The recent entry of Chinese SOCs into Africa has ignited a debate about the likely implications for the continent's development. It has similarly raised concerns as to whether the SOCs are acting at the behest of the Chinese state to exploit Africa's oil, and whether they offer African oil-producing states a more viable alternative to the Western Multinational Oil Corporations (MNOCs) that have historically dominated the continent's oil industry, with mixed results including the violation of human rights and environmental pollution in places such as Nigeria's oilrich Niger Delta region. This essay examines the ways in which oil impacts China-Africa relations, particularly regarding the debate about the implications of China's SOCs for Africa's development. Do China's SOCs represent a catalytic factor in the development of Africa's oil-producing states or are they out to exploit the continent and prop up corrupt regimes in exchange for unimpeded access to the continent's oil fields? This essay argues that a correct reading of the situation depends on an accurate interpretation of the agency of Africa's ruling elites for oil-producing countries (petro-elites) vis-à-vis Chinese SOCs.
In seeking to explain how oil features in China-Africa relations, and how it impacts the continent's development, it is important to interrogate existing information about the operations of Chinese SOCs in different African oil-producing countries. It is important to point out that oil relations between China and Africa are a useful point from which to begin to grapple with the sometimes complex nature of relations between the country and the continent. There is still a lot to learn about the nature of emerging relations, the factors, and personalities that shape or drive them and to what effect. This explains why it is necessary to seek to separate fact from fiction and present a nuanced and more accurate reading that goes beyond what is often peddled or accepted in some official, media or scholarly circles.

By examining the engagements of Chinese SOCs with African oil-producing countries such as Angola, Sudan, Chad, Gabon, Nigeria, etc., the article responds to some of the claims about the impact of the Chinese SOCs on development in oil-rich African states. Of particular interest are the claims that SOCs support authoritarian leaders of African petro-states who exploit and suppress their citizens, in order to enable SOCs to gain access to and exploit these states' oil fields. They also point to unfair labor practices by Chinese SOCs that also reportedly operate on the continent on the basis of sub-standard environmental practices. Such analyses tend to see Chinese SOCs through the lens of neo-colonialism, ${ }^{10}$ and the perpe- 


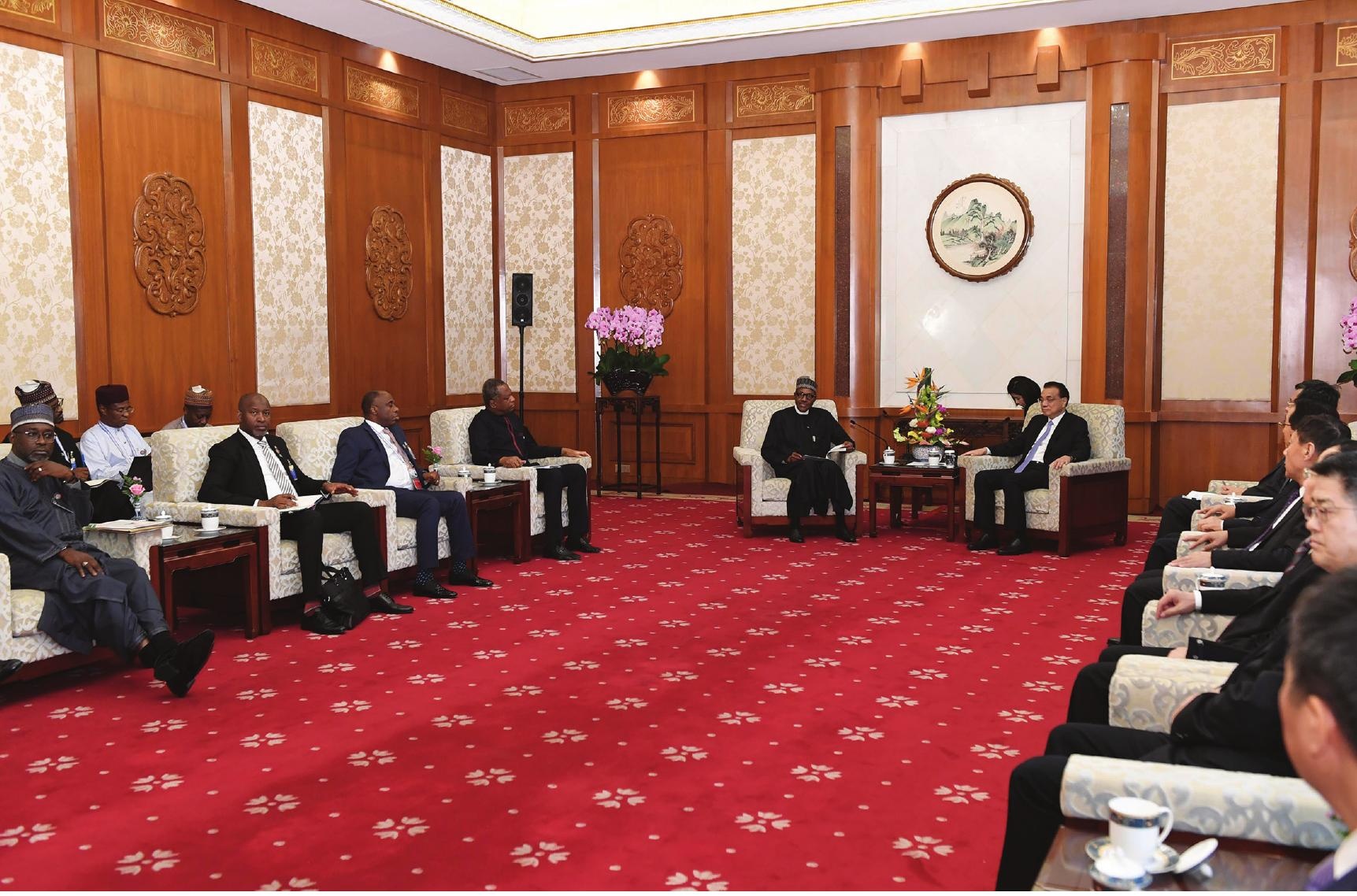

Chinese Premier Li

Keqiang met with

Nigerian President

Muhammadu

Buhari in Beijing

on September

5, 2018. Nigeria

has been China's

largest oil

provider for the

last decade.

PARKER SONG /

Getty Images

tration of the so-called African oil curse. $^{11}$

The foregoing provides the context for the framing of the China-Oil-Africa nexus in relation to an East-West scramble for Africa's oil. Some commentators have gone as far as portraying China as an energy-hungry emerging power seeking to prey on Africa's oil. The approach adopted in this essay is to question such claims and to argue that they are either flawed or exaggerate the size of the problem. This starting point provides a better-informed framing for China-Africa relations and unpacks the notion of "African agency," particularly its implications for relations and Africa's capacity to transform new opportunities to its own advantage.

The first section of this paper provides an overview of the issues, while the second involves a conceptual framing of China-Oil-Africa relations. The third section addresses the issue of how the operations of Chinese SOCs impact Africa's oil-producing countries and shape China-Africa relations. In the concluding section, a nuanced and more accurate reading of the nature of China-Africa oil relations is offered.

\section{Framing China-Africa Oil Relations}

Most studies of relations between China and Africa have been framed in terms of inter-state, or country-continent relations focusing on historical, political, socio-economic, and cultural aspects. However, some international development analysts approach relations from the perspective of Africa's dependency on Chi- 
nese 'soft' loans, resource-for-development deals, and investments, while others, usually from the Chinese side, emphasize the mutually beneficial or "win-win" nature of relations on both sides. Such debates have been largely ideologically-driven and have raged continuously with each side clinging hard to its views, with little or no chance of a resolution. However, a new line of thinking has emerged with analysts like Corkin, pointing to the agency of African state and non-state actors in the context of China-Africa relations. ${ }^{12}$ Others have also sought to move the analysis of China-Africa beyond the framework of inter-state relations, by focusing on the agency of African ruling elites. ${ }^{13}$ This new approach is useful in seeking empirical evidence to show that rather than being powerless in the face of China's dominance, some African elites and states have been able to use Chinese engagement to their own advantage.

Focusing on the interaction between the African state and elites helps us understand how some countries behave. It also facilitates a better understanding of the relationship between Africa, the Chinese state, and the various strands of the Chinese capital. In other words, it suggests the need to grapple with the different types of Chinese economic actors operating on the continent, rather than treating them as an undifferentiated whole. It is only when the agency of African states and ruling elites are considered alongside heterogeneous Chinese economic actors that we are able to move away from

\section{The entry of Chinese SOCs into} Africa's oil fields in the 1990s, when they began exploration activities in Sudan, marked the beginning of a relationship that today has resulted in the emergence of Africa as the second largest source of Chinese oil imports

simplistic assumptions, and unpack relations involving a complex set of interests on both sides.

Several questions also flow from the foregoing: are Chinese SOCs different from the MNOCs that have dominated the oil industry in Africa for the past six decades, without much to show in terms of development in the oil-endowed countries of the continent? What is the nature of relations between the Chinese state, Chinese SOCs, and African oil-producing states? Do Chinese SOCs present new opportunities (compared to Western MNOCs) for African petro-states to transform their oil industry and by extension their economies?

\section{Chinese SOCs and African Petro-States}

Shortly after China became an oil-importing country in 1993, the decision was made for Chinese SOCs, which were then relatively new, to "go out" 
globally, both to search for and win oil, and to operate as 'for profit' transnational economic enterprises in an industry that was clearly dominated by Western oil multinationals. As expected, this was an uphill task for these new entrants into a globally integrated oil industry. The entry of Chinese SOCs into Africa's oil fields in the 1990s, when they began exploration activities in Sudan, marked the beginning of a relationship that today has resulted in the emergence of Africa as the second largest source of Chinese oil imports (the largest source being the Middle East), accounting for over 1 million barrels of oil per day, or 22-23 percent of oil imports. It can, therefore, be argued that Africa has contributed to the evolution of Chinese SOCs as global oil players, operating to maximize returns on investments like their western counterparts, while providing some African petro-states with an alternative to the Western oil companies that had hitherto dominated the oil industry.

However, the narrative of the relationship between Chinese SOCs and African states has been such that the former are referred to as agents of the Chinese state. It is more instructive to frame the relationship as either being exploitative of, or beneficial to, Africans. Arguments abound as to how China has backed the authoritarian regimes of some oil-producing countries such as Sudan and reportedly supported corrupt governments in oil-rich Angola, the Republic of Congo, and Equatorial Guinea. Such initial analyses saw China's policy of "non-interference" as an excuse for pursuing its resource diplomacy in Africa. However, more recently, such views are gradually giving way, acknowledging the agency of African states and elites that are clearly taking steps to regulate, or even block Chinese oil investments when they are perceived as not in line with their country's interests. This paper provides evidence demonstrating how the elite agency has played out in three African petro-states and the broader ramifications of such agency on both sides.

\section{China and Nigeria}

Nigeria, Africa's largest oil producer, has operated an oil industry since 1958 when it commenced oil exports. With an upstream sector dominated by Western oil multinationals, it has remained Africa's largest oil producer for several decades. It is therefore significant that China developed an interest in investing in the lucrative Nigerian oil sector. In 2004, Sinopec, one of China's SOCs, signed an agreement with the Nigerian National Oil Corporation to start oil exploration activities. This was followed in 2005 by a large investment involving the China National Offshore Oil Corporation (CNOOC), which acquired a 45 percent stake in the Apo oil-for-gas field in Nigeria, valued at $\$ 3$ billion. ${ }^{14}$ These investments were followed by deals in which Chinese SOCs were granted the right of first refusal on four oil blocks in exchange for several downstream and infrastructure development projects. However, efforts 
by the CNOOC to increase its stakes in the Nigerian oil industry a year later were rebuffed by the government, which clearly asserted its decision making power over oil. There are several explanations that can be advanced for the action of the government. The first includes the role of Nigeria's petro-elites in blocking the Chinese SOCs.

According to Umejei, ${ }^{15}$ the move reflected "the interest of Nigerian elites, who felt implementing the deal would cut them off from crude oil sales on the international market," and "the influence of IOCs, who contributed in developing the Nigerian oil industry and their influential home countries." However, faced with this experience, the SOCs quickly learned more about how to manage the risks involved in seeking to establish a foothold in the Nigerian oil industry. Sinopec literally shifted gears in its engagement from acquiring oil blocks or engaging in oil-for-infrastructure deals to acquiring equity in oil-producing companies operating in Nigeria's oil fields. In line with the new approach, Sinopec acquired Addax, a Geneva-based oil company, which in turn gave it control of two offshore oil fields owned by the Nigerian subsidiary of the company. ${ }^{16}$ Not long after, Sinopec struck oil in the Niger Delta at Addax's UDELE 3 oil well in July 2010, giving it direct access to some of Nigeria's oil.

In 2012, Sinopec bought a minority stake (20 percent) in another Nigerian oil field from Total of France for the sum of $\$ 2.5$ billion, ${ }^{17}$ increasing

\section{The outcome of China-Africa}

engagements in the strategic

oil industry ultimately rests

with how Africa's petro-elites

strategically manage the

opportunities presented by

the entry of Chinese SOCs into

the continent's oil fields, rather

than any neo-imperialist

designs on the part of the

Chinese state

the level of its direct access to Nigeria's oil. Analyzing this development, Quigley, makes the point that "almost all the investments by Chinese companies are in buying shares in blocks, not sole control, so that the Chinese often rely on their Western partners to do most of the actual production work for them, releasing them from the technological demands that come with offshore drilling." ${ }^{18}$

What is not clearly mentioned, but only implied, is that Chinese SOCs have learned from their previous experience, just as the Nigerian elites continue to straddle between skepticism and acceptance of Chinese investments and aid. It is also important to observe that rather than act as a competitor, Sinopec was willing to partner with Total, a Western oil company. This reinforces the point made earlier relating to the goal of Chinese SOCs becoming interna- 


\section{The evidence suggests that}

Chinese SOC engagements

with African petro-states are

primarily driven by the quest

for profit, by minimizing risks,

and maximizing returns on

investments tionally integrated oil operators, even if this involves partnering with Western companies. Thus, rather than feed into the discourse of a scramble for Nigeria's oil between the West and China ${ }^{19}$ we see a clear example of cooperation between oil companies from China and France with the aim of advancing shared economic interests, which also provides the Chinese SOC with an opportunity to work with sophisticated Western oil technology and management style.

More important perhaps, is the point that there is no evidence that suggests Chinese SOCs intend to, or actually do, dominate the Nigerian oil industry or the petro-state. Rather, they remain marginal players whose activities focus on maximizing returns on their oil investments and cultivating an environment in which to conduct oil business. Thus, when the path to direct acquisition of oil acreages through state-to-state deals did not yield any lasting results, Chinese SOCs shifted to acquisition of oil assets through the takeover acquisition of shares in Nigerian subsidiaries of Western oil companies, and the expansion by other Chinese economic enterprises into non-oil sectors of the economy, particularly trade, construction, and infrastructure. For example, earlier this year, a subsidiary of CNOOC, the Offshore Oil Engineering Company (COOEC) and China Harbour Engineering Company won a contract to build oil pipelines for the Dangote Group, a Nigerian conglomerate. ${ }^{20}$ What this suggests is that the outcome of China-Africa engagements in the strategic oil industry ultimately rests with how Africa's petro-elites strategically manage the opportunities presented by the entry of Chinese SOCs into the continent's oil fields, rather than any neo-imperialist designs on the part of the Chinese state.

\section{China and Angola}

Angola, which ranks as the $3^{\text {rd }}$ largest source of China's annual oil imports, and its largest African oil supplier, also provides a good illustration of the agency of African governments and petro-elites in relation to Chinese SOCs. Chinese SOCs' foray into Angola commenced when Sinopec bought a 50 percent stake in Block 18, operated by BP and sold by Shell in 2004. It later partnered with the Angolan state oil corporation, Sonangol. ${ }^{21}$ Angola, being Africa's second largest oil exporter, was of strategic importance to China's oil-related, post-1993 "go out" policy. Some observers argued that apart from its oil endowment, Angola post-war reconstruction requirements presented an equal source of attraction for 



\section{While Chinese SOCs have} gradually established themselves across a growing number of established and emerging African oil-producing countries, several myths about the coming of the "Chinese dragon" to the continent's oil fields have been destroyed

pragmatic and realistic in the ways in which they engage the Angolan petro-state.

\section{China and the Two Sudans}

The case of Sudan is an instructive one in relation to China-Africa relations for several reasons. Sudan was, for all intents and purposes, one of the earliest countries outside of China where Chinese SOCs successfully struck oil in the mid-1990s, and thereafter constructed the upstream and downstream sectors of the $\mathrm{Su}$ danese oil industry. Sudan was also the first country in Africa in which Chinese SOCs invested, with the formation of the Greater Nile Petroleum Company (GNPC): a joint venture operation involving China National Petroleum Company (CNPC) 40 percent; Malaysia's Petronas, 30 percent; and India's ONGC Videsh, 25 percent. It was the GPNC that transformed Sudan into Africa's $3^{\text {rd }}$ largest oil-producing and exporting country from 1999 onwards. The GNPC was followed by Petrodar Operating Oil Company (PDOC), a consortium made up of China's CNPC, Nilepet, Malaysia's Petronas, Sinopec, and TriOcean Energy of Kuwait also operating in southern Sudan. ${ }^{24}$ Sudan was therefore instrumental in providing Chinese SOCs with the opportunity to develop their capacity and gain valuable experience investing in and building a national oil industry. ${ }^{25}$

However, following the independence of South Sudan in 2011, the fortunes of Chinese SOCs in Sudan changed, showing to some extent the level of SOC dependence on political developments in the country. Given the geography of oil endowment in Sudan, the independence of the South where most of the oil is located exposed China, which had long-term relations with Khartoum, to the vagaries of Sudanese politics. The situation was further complicated by bickering between the North and South over oil, and the outbreak of civil war in South Sudan shortly after its independence. CNPC and Sinopec had no option than to seek to adapt to the new situation in the two "Sudans." Disagreements erupted between Sudan and landlocked South Sudan, where most of the oil fields are located, over a series of issues, including the sharing of oil revenues and the payment of processing and transit fees to Sudan, through whose territory oil was piped en route to the export terminal at Port Sudan on the shores of the Red Sea. Chinese SOCs were caught in the middle of the dispute, particularly after South Sudan 
effectively shut off oil supplies which had erstwhile been exported through Sudan in the north.

Hostilities between both countries flared up in 2012, causing South Sudan to stop oil production due to a dispute over transit fees. Since then other factors, including the outbreak of civil war in South Sudan between factions of the government, and the decline in international oil prices, adversely affected returns on oil investments. Unlike the cases of Nigeria and Angola, the two Sudans presented a different kind of challenge to Chinese SOCs, which were helpless in the face of the political crises in both countries, particularly South Sudan. The challenge this posed also has implications in terms of the agency of the South Sudan petro-state and emergent elites vis-à-vis Chinese SOCs, including the ways in which the former had considerable leverage to control oil production and investments, despite their limited experience in managing the oil industry. There is very little the Chinese state could do about the situation, save for involving itself in bilateral and multilateral efforts aimed at bringing peace to the Sudans, including deploying Chinese UN peacekeepers to both countries. Chinese SOCs are also in no position to directly dictate to the government of South Sudan or influence its decision making in relation to the oil industry.

The foregoing clearly shows that assumptions of China-Africa relations being neo-colonial are too simplistic and clearly off the mark. The evi- dence suggests that Chinese SOC engagements with African petro-states are primarily driven by the quest for profit, by minimizing risks and maximizing returns on investments. This can be gleaned from the behavior of SOCs in the three case study countries where they have pragmatically adjusted to, or responded to, the decisions made by Africa's petro-states and elites.

\section{Conclusion}

China-Africa oil relations provide us with a good context for understanding the nature of the evolving relations between the country and the continent. It is clear that the texture of relations is complex and cannot be reduced to the familiar story of neo-colonialism or neo-imperialism that has dominated discourses on Africa's encounter with the West. In spite of the often ideologically colored lens with which China-Africa relations have been viewed, the cold facts tell a different story. In the first place, both still have a lot to learn from and about each other. While Chinese SOCs have gradually established themselves across a growing number of established and emerging African oil-producing countries, several myths about the coming of the "Chinese dragon" to the continent's oil fields have been destroyed. Chinese and Western oil companies are not locked in a zero-sum competition over Africa's oil resources, neither are the Chinese SOCs displacing Western oil multinationals from Africa's oil fields. Rather, Western 
companies have continued to operate Africa's most lucrative oil fields, and in some cases partner with Chinese SOCs. Another myth about China's oil-for-infrastructure deals opening Africa's oil fields to Chinese SOC investments has turned out to be exaggerated, if not disappointing. The reality of the decisive ways African petro-state have related to Chinese SOCs not only proves the point about the primacy of African agency in shaping relations, but also relates to how the new opportunities are being harnessed, for better or for worse.

China's evolving relations with Africa will, for the foreseeable future, reflect a mix of opportunities and challenges. In relation to Africa's strategic oil resource, such relations will be mediated by the relative autonomy of Chinese SOCs from the Chinese State, but will not be altogether free from the country's global aspirations. However, this relative autonomy will be confronted by the high premium placed by the governing elites of Africa's petro-states on controlling access to the oil within their countries, including the limitations it places on the capacity of Chinese SOCs to pursue their goals vis-à-vis the influence of African elites. In this complex but critical interplay of forces between the leaderships, elites, peoples, states, and economic enterprises on both sides, the question of what this moment could mean for Africa's development will depend on how effectively African states, leaders, and governing elites can purposefully use the opportunities presented by the current engagements with China to strategically advance a transformative project for the continent.

\section{Endnotes}

1. Liangyu, "Full Text of Chinese President Xi Jinping's Speech at Opening Ceremony of 2018 FOCAC Beijing Summit," Xinhua Net, (September 3 , 2018), retrieved October 22, 2018, from http:// www.xinhuanet.com/english/2018-09/03/c_ 129946189.htm.

2. Gyude Moore, "Opinion: Trade War Open's Possibilities for Africa-China Relations," Caixin, (September 7, 2018), retrieved October 22, 2018, from https://www.caixinglobal.com/2018-09-07/ opinion-trade-war-opens-possibilities-for-africachina-relations-101323632.html; Luo Shanshan, "China Remains Africa's Largest Trading Partner for 9 Consecutive Years," People's Daily Online, (August 31, 2018), retrieved December 14, 2018, from http://en.people.cn/n3/2018/0831/c900009495973.html.

3. "Remarks by President Cyril Ramaphosa during the China-Africa High Level Dialogue with Business Representatives Forum on China-Africa Cooperation," The Department of International Relations and Cooperation, Republic of South Africa, (September 3, 2018), retrieved October 22, 2018, from http://www.dirco.gov.za/docs/ speeches/2018/cram0903.htm.

4. Abdi Latif Dahir, "Why 2018 Marks a Critical Milestone in China Africa Relations," Quartz Africa, (September 10, 2018), retrieved October 24, 2018, from https://qz.com/africa/1384079/chinaafrica-relations-make-a-crucial-turning-point-in2018/.

5. Adam Tiffen, "The New Neo-colonialism of Africa," Center of Africa, (2014), retrieved July 9, 2018, from http://blogs.lse.ac.uk/africaatlse/ 2014/09/26/the-new-neo-colonialism-in-africa/; Michael Pillsbury, The Hundred Year Marathon: China's Secret Strategy to Replace America's Global Power, (New York: Henry Holt and Co, 2015).

6. Chen $\mathrm{Xi}$, "Why Fears of China's Neocolonialism in Africa Ring False in the Face of Numbers that Tell a Different Tale," South China Morning Post, (September 25,2018), retrieved October 24, 2018, from https://www.scmp.com/comment/ insight-opinion/united-states/article/2165489/ why-fears-chinas-neocolonialism-africa-ring; Beth Walker, "How Africa Is Changing Chinese Oil Companies," China Dialogue, (December 10, 2014), retrieved July 9, 2018, from https://www. 
chinadialogue.net/article/show/single/en/7583How-Africa-is-changing-Chinese-oil-companies.

7. He Wenping, "China Policy Balancing," China Security, Vol. 1, No. 3 (2007).

8. Fantu Cheru, "Emerging Southern Powers and New Forms of South-South Cooperation: Ethiopia's Strategic Engagement with China and India," Third World Quarterly, Vol. 37, No. 4 (2016).

9. Cheru, "Emerging Southern Powers and New Forms of South-South Cooperation: Ethiopia's Strategic Engagement with China and India."

10. Suisheng Zhao, "A Neo-Colonialist Predator or Development Partner? China's Engagement and Rebalance in Africa," Journal of Contemporary China, Vol. 23, No. 90 (2014); Elizabeth Manero, "China's Investment in Africa: The New Colonialism?" Harvard Political Review, (February 3, 2017), retrieved July 21, 2018, from http://harvardpolitics.com/world/chinas-investment-in-africa-the-new-colonialism/.

11. Cyril Obi, "African Oil in the Security Calculations of China in India," in Fantu Cheru and Cyril Obi (eds.), The Rise of China and India in Africa: Challenges, Opportunities and Critical Interventions, (London: Zed Books, 2010).

12. Lucy Corkin, "Forum: African Agency in the Context of China in African Relations," African East-Asian Affairs, Vol. 1/2 (June 2015), pp. 163172.

13. Giles Mohan and Ben Lampert, "Negotiating China: Inserting African Agency in China-Africa Relations," African Affairs, Vol. 112, No. 446 (2013).

14. Mohan and Lampert, "Negotiating China: Inserting African Agency in China-Africa Relations."

15. Emeka Umejei, “Why Did China's Infrastructure for Resources Deal Fail in Nigeria?" African Arguments, (September 2, 2013), retrieved July 2013, from http://africanarguments.org/2013/09/02/ why-did-chinas-infrastructure-for-resourcesdeal-fail-in-nigeria-by-emeka-umejei/.

16. Umejei, "Why Did China's Infrastructure for Resources Deal Fail in Nigeria?"
17. Michael Kavanagh, "Total and Sinopec Agree Nigeria Oil Deal," Financial Times, (November 19, 2012), retrieved July 21, 2018, from https://www. ft.com/content/0f070cfa-3268-11e2-ae2f-00144 feabdc0; Fox Hu, Zijing Wu, and Tara Patel, "Sinopec Said to Buy Nigeria Oil Blocks from French Total," Bloomberg, (November 6, 2012), retrieved July 21, 2018, from https://www.bloomberg.com/news/ articles/2012-11-06/sinopec-said-to-buy-nigeriaoil-blocks-from-french-total.

18. Sam Quigley, "Chinese Oil Acquisitions in Nigeria and Angola," American University in Cairo, (June 1, 2014), retrieved July 21, 2018, from http://schools.aucegypt.edu/huss/pols/Khamasin/Pages/article.aspx?eid=14.

19. Ian Taylor, "Dependency Redux: Why Africa Is Not Rising," Review of African Political Economy, Vol. 43, No. 147 (2014), p. 403.

20. "Chinese Firms to Start Building Sub-sea Pipeline Installation in Nigeria," Xinhua Net, (January 13, 2018), retrieved July 22, 2018, from http://www.xinhuanet.com/english/2018-01/13/ C_136893514.htm.

21. Lucy Corkin, "Uneasy Allies: China's Evolving Relations with Angola," Journal of Contemporary African Studies, Vol. 29, No. 2, (2011); Ana Alves, "Chinese Economic Statecraft: A Comparative Study of China's Oil-backed Loans to Angola and Brazil," Journal of Current Chinese Affairs, Vol. 42, No. 1 (2013).

22. Corkin, "Uneasy Allies: China's Evolving Relations with Angola"; Alves, "Chinese Economic Statecraft: A Comparative Study of China's Oilbacked Loans to Angola and Brazil."

23. Mohan and Lampert, "Negotiating China: Inserting African Agency in China-Africa Relations."

24. Luke Patey, "Learning in Africa: China's Overseas Oil Investments in Sudan and South Sudan," Journal of Contemporary China, Vol. 26, No. 107 (2017), pp. 760-761.

25. Luke Patey, The New Kings of Crude: China, India and the Global Struggle for Oil in Sudan and South Sudan, (London: Hurst, 2014), pp. 111-120. 


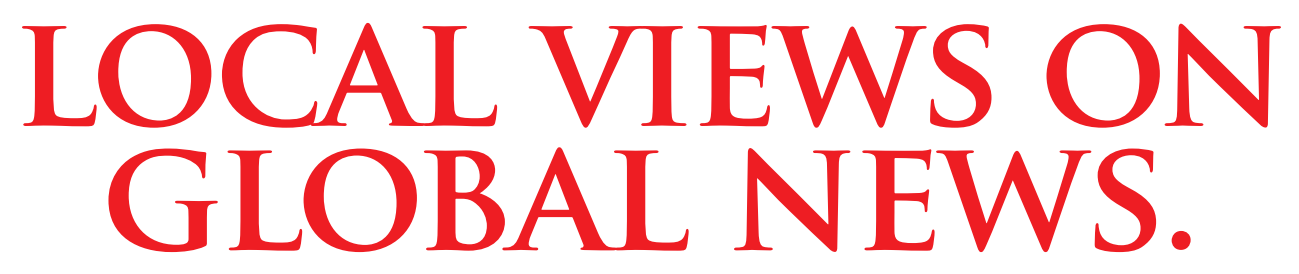
READ DAILY TO KEEP UP WITH CHANGING TURKEY AND THE WORLD.

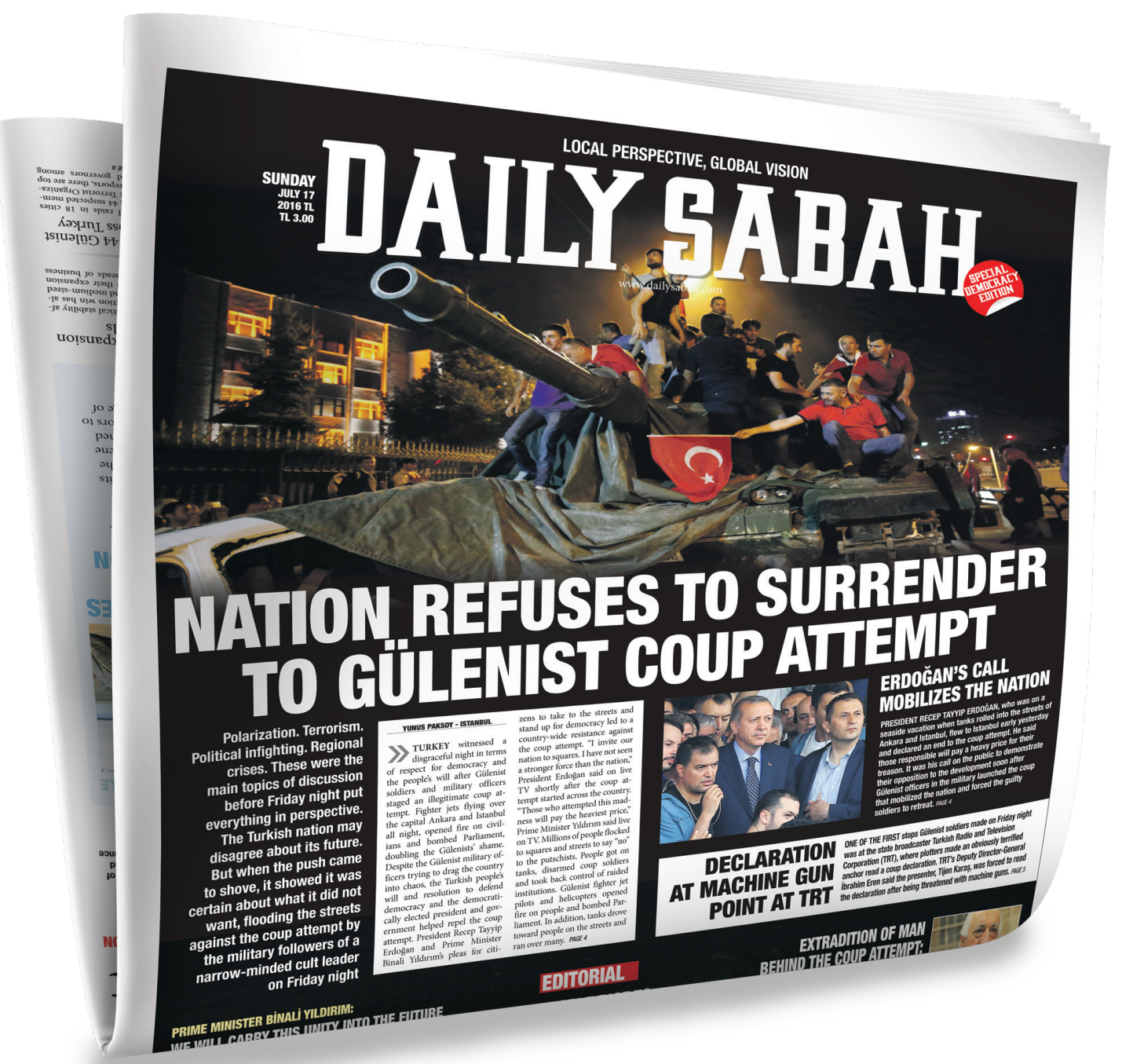

www.dailysabah.com 